\title{
HSS Scholars \& Scientists Workgroup Report
}

Shira Eller, William Gunn, Diane Scott Lichter, Joan Lippincott, Aimee Nixon, Concetta Seminara, Roger Schonfeld

\section{Summary}

The HSS Scholars \& Scientists workgroup was convened in recognition of the diverse dynamics and requirements of different research communities, particularly within the Humanities and the Social Sciences (HSS). Within these disciplines there are significant differences in research culture, practices, and access to funding, highlighting that a different approach may be required to embed an open science environment.

The fundamental fact that bears repeating is that HSS scholars in the United States simply do not receive the level of funding or government-mandated support that STEM scholars receive. Without that key funding infrastructure in place, we cannot realistically hope for further open access (OA) progress in HSS in the U.S.

Unfortunately, 'thoughtful conversations' among earnest academic librarians and publishers are not enough to solve this serious funding gap--at least not in the immediate future. A strong lobbying force needs to approach the U.S. Congress and organizations such as the National Endowment for the Arts for more OA funding in the Social Sciences and Humanities. However, as anyone who follows current U.S. politics is aware, education funding is not a priority of the current administration. If anything, there is talk of de-funding the NEA and other major academic funding bodies.

On a brighter note, sales professionals for academic publishers are trying to find creative ways to promote open access by offering special article processing charge (APC) rate packages to universities.

The approach of the HSS and Scientists workgroup was to map out the publishing environment for the following four areas, first looking at publication practices and preferences (Table 1):

- Clinical Medicine

- Other Sciences

- Social Sciences

- Humanities.

The group then sought to document both the challenges (Table 2) and opportunities (Table 3) for each area. For this further analysis Clinical Medicine and Other Sciences were combined under the classification "STEM".

\section{Analysis}

The analysis of challenges and opportunities highlighted that there are more areas of convergence than initially anticipated, suggesting that some issues / opportunities could be tackled on a more universal basis. Examples included raising

(C) 2017 OSI2017 HSS Scholars \& Scientists Workgroup. This open access article is distributed under the Creative Commons Attribution 4.0 International License. This document reflects the combined input of the authors listed here (in alphabetical order by last name) as well as contributions from other OSI2017 delegates. The findings and recommendations expressed herein do not necessarily reflect the opinions of the individual authors listed here, nor their agencies, trustees, officers, or staff. 
awareness and understanding, and incentivising behavior.

Analysis did highlight, however, that some areas of divergence remain significant; i.e. access to funding, fundamental differences in publishing practices. This highlights a need for a bottom up approach from within individual subject communities.

\section{Recommendations}

Mapping out the characteristics of these different research communities proved a valuable exercise, as it helped the HSS and Scientists workgroup to assess where universal solutions could be applied. One key recommendation from the group was a drive on education and awareness, focusing particularly on the benefits and incentives of an open science environment.

The main recommendation from the group was that, in recognition that there remain a number of areas of significant convergence, disciplines need to find their own approach and solutions need to come from within. Some of the most successful implementations of an open science environment have come from within individual communities, e.g. Physics. It was suggested that a research community within Social Sciences or the Humanities could be encouraged to act as a test case, working cohesively to suggest and trial new approaches.

\section{Tables}

Table 1: Publishing Environment for Core Research Areas.

\begin{tabular}{|l|l|l|l|l|}
\hline & $\begin{array}{l}\text { Clinical } \\
\text { Medicine }\end{array}$ & $\begin{array}{l}\text { Other } \\
\text { Sciences }\end{array}$ & $\begin{array}{l}\text { Social } \\
\text { Sciences }\end{array}$ & Humanities \\
\hline $\begin{array}{l}\text { Publishing } \\
\text { environment }\end{array}$ & $\begin{array}{l}\text { Journals: Vital } \\
\text { for tenure; } \\
\text { Strong OA } \\
\text { models yielding } \\
\text { broad transition } \\
\text { Books: Generate } \\
\text { royalties }\end{array}$ & $\begin{array}{l}\text { Journals: } \\
\text { Vital for } \\
\text { tenure } \\
\text { Strong OA } \\
\text { models } \\
\text { yielding } \\
\text { broad } \\
\text { transition } \\
\text { Books: } \\
\text { Generate } \\
\text { royalties }\end{array}$ & $\begin{array}{l}\text { Journals: } \\
\text { Vital for } \\
\text { tenure } \\
\text { OA models } \\
\text { may not be } \\
\text { all that } \\
\text { strong }\end{array}$ & $\begin{array}{l}\text { Monographs are } \\
\text { the gold standard } \\
\text { for tenure and } \\
\text { promotion } \\
\text { Journals } \\
\text { secondary }\end{array}$ \\
& & & \\
& & & \\
& & & \\
\hline
\end{tabular}


Table 2: Challenges of achieving an Open Science Environment.

\begin{tabular}{|c|c|c|c|}
\hline & STEM & Social Sciences & Humanities \\
\hline Challenges & $\begin{array}{l}\text { Pressure to publish } \\
\text { Few incentives for } \\
\text { openness beyond } \\
\text { mandates. Perceived } \\
\text { COI by some } \\
\text { Confusion about licenses } \\
\text { Societies - some } \\
\text { groups/vendors resist } \\
\text { loss of revenue stream } \\
\text { T\&P slow evolution of } \\
\text { assessment practices, } \\
\text { incentives need } \\
\text { expansion } \\
\text { Global South researchers } \\
\text { lack funding } \\
\text { Little incentive to } \\
\text { publish negative data or } \\
\text { replications } \\
\text { Large multigroup works } \\
\text { to agree } \\
\text { Lack of global } \\
\text { norms/standards to } \\
\text { expand joint } \\
\text { collaborations } \\
\text { Increasing specialization } \\
\text { inhibits coordination } \\
\text { Weakened journal brand } \\
\text { as search engines have } \\
\text { become the entry point } \\
\text { to the literature } \\
\text { Privacy/regulation issues } \\
\text { inhibit data sharing. } \\
\text { Who owns the datasets } \\
\text { to be mined varies. }\end{array}$ & $\begin{array}{l}\text { Perception of low- } \\
\text { quality scholarship } \\
\text { Soc Sci societies see } \\
\text { OA as cannibalizing } \\
\text { content/cutting } \\
\text { journals' revenue } \\
\text { stream } \\
\text { Market confusion } \\
\text { about predatory } \\
\text { publishers } \\
\text { No author funding in } \\
\text { most Soc Sci } \\
\text { disciplines } \\
\text { Not enough OA } \\
\text { activity (i.e. critical } \\
\text { mass) to support full } \\
\text { conversion to OA in } \\
\text { most areas } \\
\text { Very little cohesion } \\
\text { among the Soc Sci } \\
\text { discipline } \\
\text { communities } \\
\text { Not the same drivers, } \\
\text { motivations, mandates } \\
\text { to publish OA }\end{array}$ & $\begin{array}{l}\text { Gold OA is } \\
\text { confused with } \\
\text { vanity publishing, } \\
\text { which has a much } \\
\text { worse rep in } \\
\text { humanities } \\
\text { No mandates } \\
\text { Ethics policies } \\
\text { doesn't address } \\
\text { openness } \\
\text { No author funding } \\
\text { in the A\&H } \\
\text { disciplines } \\
\text { Perception of low- } \\
\text { quality scholarship } \\
\text { No indexes like } \\
\text { PubMed } \\
\text { Idea that 'Open' = } \\
\text { larger risk of being } \\
\text { plagiarized or } \\
\text { copied } \\
\text { Slow evolution of } \\
\text { assessment } \\
\text { practices at } \\
\text { institutions } \\
\text { Permission issues } \\
\text { with visual arts } \\
\text { (artwork) can be } \\
\text { obstructive }\end{array}$ \\
\hline
\end{tabular}


Table 3: Opportunities for creating an Open Science Environment.

\begin{tabular}{|c|c|c|c|}
\hline & STEM & Social Sciences & Humanities \\
\hline Opportunities & $\begin{array}{l}\text { Better engagement of } \\
\text { public --more secure } \\
\text { funding, better } \\
\text { policy/health } \\
\text { Improved discovery } \\
\text { Data and pubs mining } \\
\text { More timely access to } \\
\text { research } \\
\text { Potential to Identify } \\
\text { and establish } \\
\text { standards, efficiencies, } \\
\text { areas for building on } \\
\text { research } \\
\text { Support future } \\
\text { researchers and } \\
\text { caregivers regardless of } \\
\text { funding source, geo, } \\
\text { resources } \\
\text { Effective linking adds } \\
\text { historical tracking and } \\
\text { adds responsibility and } \\
\text { assigns credit } \\
\text { Supports new business } \\
\text { models based on } \\
\text { reuse/analytics } \\
\text { Construction of field- } \\
\text { specific factbases } \\
\text { (chemical material } \\
\text { properties, antibody } \\
\text { properties, geophysical } \\
\text { characteristics, etc.) } \\
\text { Easier to make } \\
\text { assessment more } \\
\text { comprehensive, } \\
\text { including public impact } \\
\text { and other scholarly } \\
\text { products like data \& } \\
\text { software }\end{array}$ & $\begin{array}{l}\text { Providing opportunities } \\
\text { /publication venues } \\
\text { and much-needed } \\
\text { access for scholars } \\
\text { from the Developing } \\
\text { World/Global South } \\
\text { Integrated interactive } \\
\text { tables / datasets } \\
\text { Integrated simulation } \\
\text { Meta-analysis of large } \\
\text { bodies of accessible } \\
\text { work increases } \\
\text { confidence in individual } \\
\text { reports } \\
\text { Interdisciplinary } \\
\text { collaborations are easier } \\
\text { to find/undertake } \\
\text { Encourage a } \\
\text { community within Soc } \\
\text { Sci to act as case study } \\
\text { / trail blazers for Open } \\
\text { Practices }\end{array}$ & $\begin{array}{l}\text { Scholars are } \\
\text { recognizing the } \\
\text { advantages of } \\
\text { openness (ex. } \\
\text { MLA Commons) } \\
\text { Scholars working } \\
\text { in the Digital } \\
\text { Humanities are } \\
\text { on board with } \\
\text { openness } \\
\text { Early-stage } \\
\text { scholars } \\
\text { monographs } \\
\text { Multi-media / } \\
\text { non-text content } \\
\text { GLAMs are } \\
\text { opening up } \\
\text { images and other } \\
\text { content } \\
\text { Access to } \\
\text { digitized } \\
\text { vulnerable } \\
\text { cultural heritage } \\
\text { artifacts }\end{array}$ \\
\hline
\end{tabular}




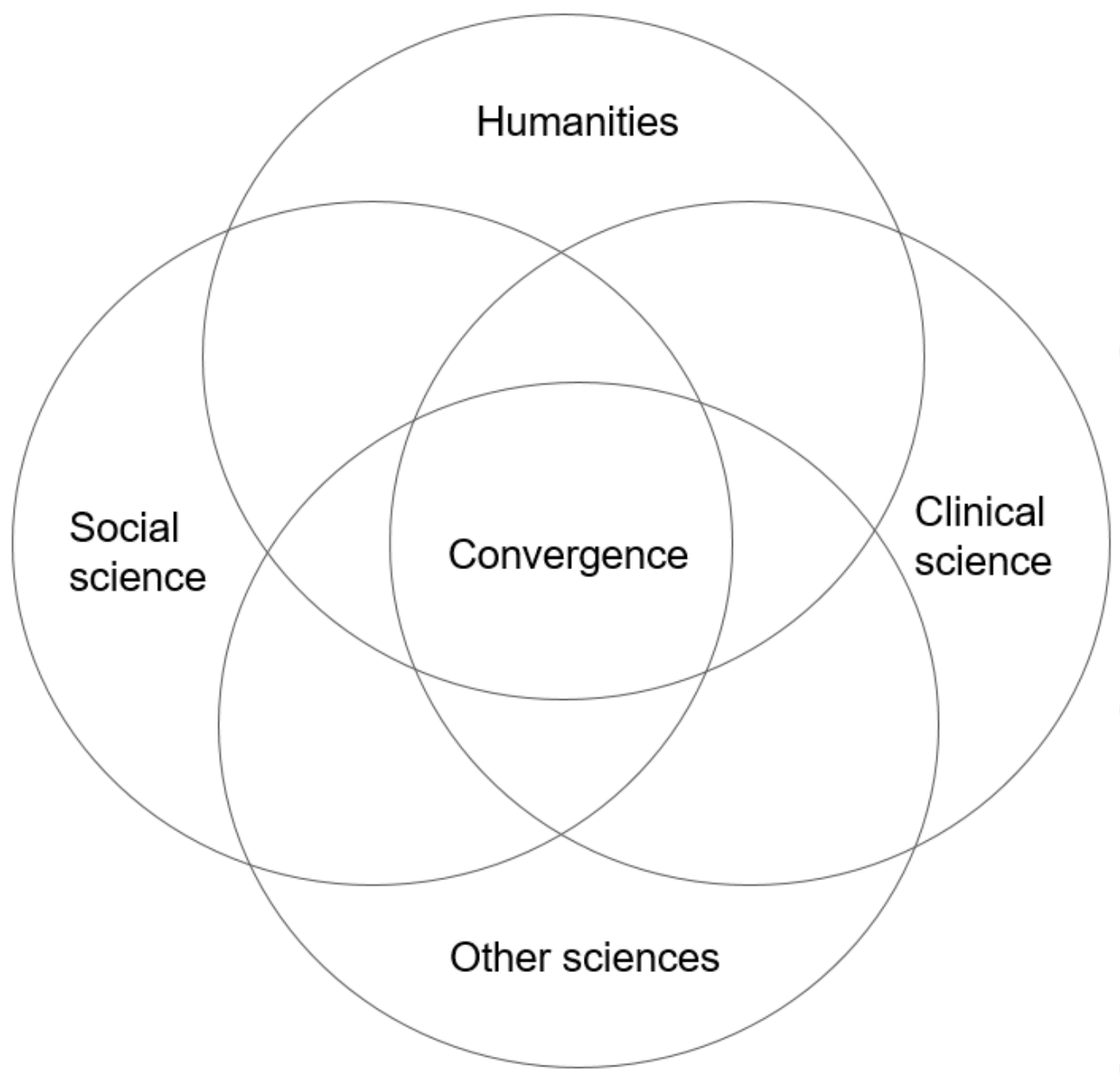

\section{Convergence}

$+\quad$ Visibility

$+\quad$ Public engagement

$+\quad$ Preservation

$+\quad$ Text and data mining

$+\quad$ Interdisciplinarity

- $\quad$ Lack of understanding

- $\quad$ How to assess

- Incentives

- $\quad$ Lack funding/business model

- $\quad$ Trust (brand weakness/vanity press) 


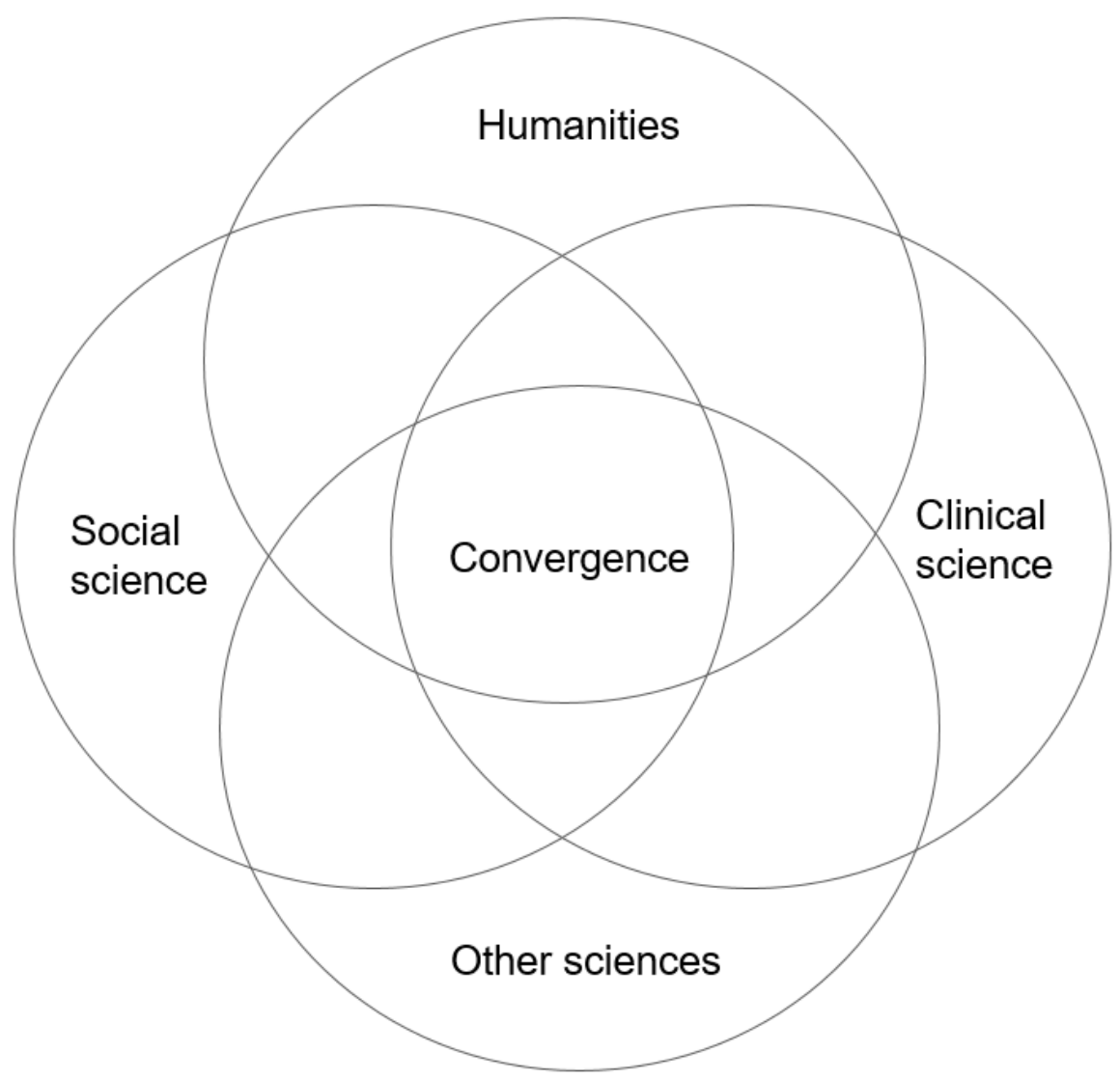

\section{Divergence}

Humanities

Rights acquisition is harder

Reputation of author-pays

Funding

Content half-life

More monographs/books

$\underline{\text { Social science }}$

Patient privacy

Funding

$\underline{\text { STEM }}$

Patient privacy

Journal-based assessment

Funder mandates 


\section{HSS Scholars \& Scientists Workgroup:}

Shira Eller, Art \& Design Librarian, George Washington University

William Gunn, Director of Scholarly Communications, Elsevier

Diane Scott-Lichter, Sr. Vice President, Publishing, American College of Physicians; Chair, AAP/PSP Executive Committee

Joan Lippincott, Associate Executive Director, Coalition for Networked Information Aimee Nixon, Head of Open Access Publishing, Emerald

Concetta Seminara, Editorial Director, Social Science \& Humanities Journals, Routledge/Taylor \& Francis

Roger Schonfeld, Director, Library and Scholarly Communication Program, Ithaka S+R 